\title{
MODELING AND SIMULATION OF LEAD-FREE PEROVSKITE SOLAR CELL USING SCAPS-1D
}

\author{
Omeiza Abdulmalik Muhammed ${ }^{a}$, Eli Danladi ${ }^{\mathrm{b}, \mathrm{e}, *}$, Peter Henry Boduku ${ }^{\mathrm{c}}$, Jamila Tasiu ${ }^{\mathrm{c}}$, \\ Muhammad Sani Ahmad ${ }^{c}$, Nuhu Usmand \\ ${ }^{a}$ Department of Physics, Bayero University, Kano, Nigeria \\ ${ }^{b}$ Department of Physics, Nigerian Defence Academy, Kaduna, Nigeria \\ 'Department of Physics, Kaduna State University, Kaduna, Nigeria \\ ${ }^{d}$ Department of Mathematical Sciences, Kaduna State University, Kaduna, Nigeria \\ ${ }^{e}$ Department of Physical Sciences, Greenfield University, Kaduna, Nigeria \\ *Coresponding Author: danladielibako@gmail.com,tel.+2348063307256 \\ Received January 28, revised March 27, 2021; accepted April 19, 2021
}

\begin{abstract}
In this work, the effect of some parameters on tin-based perovskite $\left(\mathrm{CH}_{3} \mathrm{NH}_{3} \mathrm{SnI}_{3}\right)$ solar cell were studied through device simulation with respect to adjusting the doping concentration of the perovskite absorption layer, its thickness and the electron affinities of the electron transport medium and hole transport medium, as well as the defect density of the perovskite absorption layer and hole mobility of hole transport material (HTM). A device simulator; the one-dimensional Solar Cells Capacitance Simulator (SCAPS-1D) program was used for simulating the tin-based perovskite solar cells. The current-voltage $(\mathrm{J}-\mathrm{V})$ characteristic curve obtained by simulating the device without optimization shows output cell parameters which include; open circuit voltage $\left(V_{o c}\right)=0.64 \mathrm{~V}$, short circuit current density $\left(J_{s c}\right)=28.50 \mathrm{~mA} / \mathrm{cm}^{2}$, fill factor $(\mathrm{FF})=61.10 \%$, and power conversion efficiency $(\mathrm{PCE})=11.30 \%$ under AM1.5 simulated sunlight of $100 \mathrm{~mW} / \mathrm{cm}^{2}$ at $300 \mathrm{~K}$. After optimization, values of the doping concentration, defect density, electron affinity of electron transport material and hole transport material were determined to be: $1.0 \times 10^{16} \mathrm{~cm}^{-3}, 1.0 \times 10^{15} \mathrm{~cm}^{-3}, 3.7 \mathrm{eV}$ and $2.3 \mathrm{eV}$ respectively. Appreciable values of solar cell parameters were obtained with $J_{s c}$ of $31.38 \mathrm{~mA} / \mathrm{cm}^{2}, V_{o c}$ of $0.84 \mathrm{~V}$, FF of $76.94 \%$ and PCE of $20.35 \%$, when compared with the initial device without optimization, it shows improvement of $\sim 1.10$ times in $J_{s c}, \sim 1.80$ times in PCE, $\sim 1.31$ times in Voc and $\sim 1.26$ time in FF. The results show that the lead-free $\mathrm{CH}_{3} \mathrm{NH}_{3} \mathrm{SnI}_{3}$ perovskite solar cell which is environmentally friendly is a potential solar cell with high theoretical efficiency of $20.35 \%$.
\end{abstract}

KEYWORDS: electron transport layer, hole transport layer, perovskite solar cell, photovoltaic, SCAPS-1D, copper iodide.

Recently, perovskite solar cells have taken the renewable energy community by storm and subsequently gained attention of several world's researchers due to its high performance and low cost. Perovskite absorber has many advantages for its applications in photovoltaic devices, including tuned band gap, small exciton energy, excellent bipolar carrier transport, long electron-hole diffusion, and amazingly high tolerance to defects [1-3]. Owing to this astonishing properties exhibited by this material, its efficiency has increased from $3.9 \%$ [4] to over $23 \%$ [5,6]. However, there are some limitations in realizing its outdoor applications, such as instability, electron transport resistance between $\mathrm{TiO}_{2}$ and perovskite absorber, the use of poisonous lead in the absorber etc. The PSCs free from poisonous lead have become the subject of interest due to its environmental friendliness. Perovskite absorber based on tin $\left(\mathrm{CH}_{3} \mathrm{NH}_{3} \mathrm{SnI}_{3}\right)$ have become an option to perovskite based on lead $\left(\mathrm{CH}_{3} \mathrm{NH}_{3} \mathrm{PbX}\right.$ ), because of its non-toxic nature, lower band gap of $1.3 \mathrm{eV}$ and a broad visible absorption spectrum than the $\mathrm{CH}_{3} \mathrm{NH}_{3} \mathrm{PbX}_{3}$ [7].

Researchers focus mostly on enhancing the PCE of PSCs, while overlooking the danger it poses to the environment. For PSCs technologies to compete with other photovoltaic systems, the need for a Lead free-perovskite device is worth considering so as to have devices with high PCE, low cost and carbon free systems. Most researches on PSCs is carried out using $\mathrm{CH}_{3} \mathrm{NH}_{3} \mathrm{PbX}_{3}$ material with only few research with other perovskite materials. Most research on PSCs are on material film growth, film treatment, characterization on the various photoanodes and on the finished devices. However, the interpretation of the results acquired by experiment has often not been easy. The reason is because good theoretical models and available data on defect, band offsets, carrier density at grain boundaries, and the interfaces has not been established. Therefore, good numerical model to establish PV devices is an indispensable tool to better grasp the underlying mechanism preventing optimum performance of PSCs devices [5]. In this paper, numerical modelling and simulation of lead free PSCs with inorganic copper iodide as HTM was done with SCAPS. The results show that the leadfree $\mathrm{CH}_{3} \mathrm{NH}_{3} \mathrm{SnI}_{3}$ perovskite solar cell which is environmentally friendly is a potential solar cell with high theoretical efficiency of $20.35 \%$ when simulated with alternate $\mathrm{CuI}$ as hole transport layer.

\section{DEVICE SIMULATION PARAMETERS}

The simulation of the perovskite solar cell was based on the n-p configuration which can be simulated using any thin-film simulator and therefore considered similar to the structure of thin film semiconductor based solar cell as well as a planar heterojunction.

The planar heterojunction configuration has been adopted for $\mathrm{CH}_{3} \mathrm{NH}_{3} \mathrm{SnI}_{3}$ based solar cell with layer configuration of glass substrate/TCO (transparent conducting oxide)/ETM $\left(\mathrm{TiO}_{2}\right) /$ absorber layer $\left(\mathrm{CH}_{3} \mathrm{NH}_{3} \mathrm{SnI}_{3}\right) / \mathrm{HTM}(\mathrm{CuI}) /$ back metal contact $(\mathrm{Au})$ as shown in Figure 1 (a) while the energy band diagram is shown in Figure 1 (b). 
Table 1 shows the values of the most useful cell parameters required for the simulation. These values were chosen on the basis of theoretical considerations, experimental data and existing literature or in some cases, reasonable estimates. Most of the parameters used for the absorber layer were extracted from the literature [8] while the parameters for interface layer in the Table 2 was also chosen based on work reported by Farhana et al [8]. The remaining parameters were estimated, the most important parameters (bandgap $\left(E_{g}\right)$, electron mobility $\left(\mu_{n}\right)$, hole mobility $\left(\mu_{n}\right)$ etc.) for the simulation were obtained from review of literature. The work function of the cathode electrode $(\mathrm{Au})$ is $5.1 \mathrm{eV}$ which serves as back metal contact.

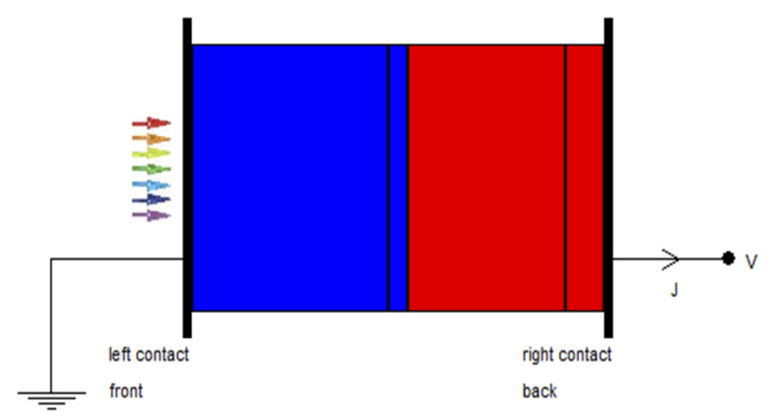

a

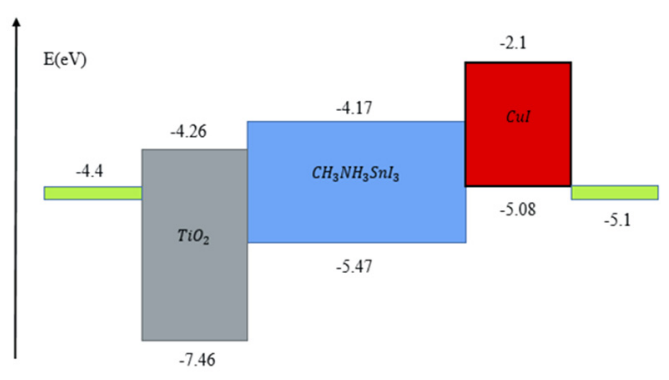

b

Figure 1. (a) Simulated solar cell structure (SCAPS-1D), (b) Energy band diagram

Table 1. Parameters used for simulation of perovskite solar cell structures using SCAPS-1D.

\begin{tabular}{|c|c|c|c|c|}
\hline Parameters & TCO & ETM $\left(\mathrm{TiO}_{2}\right)$ & Absorber & HTM (CuI) \\
\hline Thickness $(\mu \mathrm{m})$ & $0.5[8]$ & $0.05[10]$ & $0.40[5]$ & 0.10 \\
\hline Band gap energy $\mathrm{Eg}(\mathrm{eV})$ & $3.5[7]$ & $3.20[10]$ & $1.30[8]$ & 2.98[9] \\
\hline Electron affinity $\chi(\mathrm{eV})$ & $4.0[5]$ & $4.26[9]$ & $4.20[8]$ & $2.10[9]$ \\
\hline Relative permittivity $\epsilon_{\mathrm{r}}$ & 9 & $50[8]$ & $10[8]$ & $6.50[9]$ \\
\hline Effective conduction band density $\mathrm{Nc}\left(\mathrm{cm}^{-3}\right)$ & $2.0 \times 10^{18}$ & $1.0 \times 10^{21}$ & $1.0 \times 10^{18}$ & $2.8 \times 10^{19}$ \\
\hline Effective valance band density $\mathrm{Nv}\left(\mathrm{cm}^{-3}\right)$ & $1.8 \times 10^{19}$ & $2.0 \times 10^{20}$ & $1.0 \times 10^{18}$ & $1.0 \times 10^{19}$ \\
\hline Electron mobility $\mu \mathrm{n}\left(\mathrm{cm}^{2} \mathrm{~V}^{-1} \mathrm{~s}^{-1}\right)$ & $20[9]$ & $6.0 \times 10^{-3}$ & 1.6 & $1.69 \times 10^{-4}$ \\
\hline Hole mobility $\mu \mathrm{p}\left(\mathrm{cm}^{2} \mathrm{~V}^{-1} \mathrm{~s}^{-1}\right)$ & 8 & $6.0 \times 10^{-3}$ & 1.6 & $1.69 \times 10^{-4}$ \\
\hline Donor concentration ND $\left(\mathrm{cm}^{-3}\right)$ & $2 \times 10^{19}$ & $5 \times 10^{19}$ & 0 & 0 \\
\hline Acceptor concentration NA $\left(\mathrm{cm}^{-3}\right)$ & 0 & 0 & $3.2 \times 10^{15}$ & $1 \times 10^{18}$ \\
\hline Defect density $\mathrm{Nt}\left(\mathrm{cm}^{-3}\right)$ & $1 \times 10^{15}$ & $1 \times 10^{15}$ & $4.5 \times 10^{16}$ & $1 \times 10^{15}$ \\
\hline
\end{tabular}

Table 2: Parameters of interface layer [8]

\begin{tabular}{|l|c|c|c|}
\hline Parameters & $\mathbf{C H}_{\mathbf{3}} \mathbf{N H}_{\mathbf{3}} \mathbf{S n I}_{\mathbf{3}}$ & $\mathbf{T i O}_{\mathbf{2}} / \mathbf{C H}_{\mathbf{3}} \mathbf{N H}_{\mathbf{3}} \mathbf{S n I}_{\mathbf{3}}$ interface & $\mathbf{C H}_{\mathbf{3}} \mathbf{N H}_{\mathbf{3}} \mathbf{S n I} \mathbf{I}_{\mathbf{3}} / \mathbf{C u I}$ interface \\
\hline Defect type & Neutral & Neutral & Neutral \\
Capture cross section for electrons $\left(\mathrm{cm}^{2}\right)$ & $2 \times 10^{-15}$ & $2 \times 10^{-15}$ & $2 \times 10^{-13}$ \\
Capture cross section for holes $\left(\mathrm{cm}^{2}\right)$ & $2 \times 10^{-15}$ & $2 \times 10^{-15}$ & $2 \times 10^{-13}$ \\
Energetic distribution & Gaussian & Single & Single \\
Energy level with respect to Ev $(\mathrm{eV})$ & 0.500 & 0.650 & 0.650 \\
Characteristic energy $(\mathrm{eV})$ & 0.1 & 0.1 & 0.1 \\
Total density $\left(\mathrm{cm}^{-3}\right)$ & $1 \times 10^{15}-1 \times 10^{19}$ & $1 \times 10^{18}$ & $1 \times 10^{18}$ \\
\hline
\end{tabular}

The J-V characteristic curve obtained by simulating with the data in Table 1 is shown in Figure 2 with the output cell parameters $V_{o c}=0.64 \mathrm{~V}, J_{s c}=28.50 \mathrm{~mA} / \mathrm{cm}^{2}, \mathrm{FF}=61.10 \%$, and PCE $(\eta)=11.30 \%$ under AM1.5 simulated sunlight of $100 \mathrm{~mW} / \mathrm{cm}^{2}$ at $300 \mathrm{~K}$.

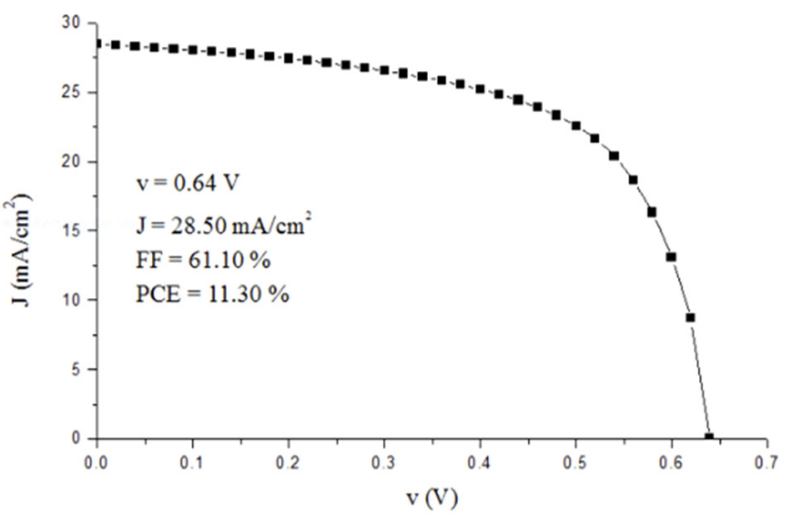

Figure 2. J-V curve of PSC with initial parameters

\section{RESULTS AND DISCUSSION \\ The effect of Doping Concentration $\left(\mathrm{N}_{\mathrm{A}}\right)$ of Perovskite Absorption Layer}

The perovskite $\mathrm{CH}_{3} \mathrm{NH}_{3} \mathrm{SnX}$ (where $\mathrm{X}=\mathrm{Cl}, \mathrm{Br}, \mathrm{I}$ ) experiences instability due to atmospheric moisture content thereby making the $S n^{2+}$ ion to oxidize into $\mathrm{Sn}^{4+}$ analogue with enhanced stability within itself during doping process and hence acting as a dopant with p-type nature. In a study demonstrated earlier using $\mathrm{CH}_{3} \mathrm{NH}_{3} \mathrm{SnI}_{3}$ as absorber, the $\mathrm{N}_{\mathrm{A}}$ was varied between $10^{14} \mathrm{~cm}^{-3}$ to $10^{19} \mathrm{~cm}^{-3}[10,11]$. In our own work, we varied the doping concentration of the $\mathrm{CH}_{3} \mathrm{NH}_{3} \mathrm{SnI}_{3}$ layer from $10^{13} \mathrm{~cm}^{-3}$ to $10^{17} \mathrm{~cm}^{-3}$ and compared their photovoltaic properties.

Table 3 shows photovoltaic parameters with different doping concentration. 
Table 3. Dependence of solar cell performance on the doping concentration of Absorber layer

\begin{tabular}{|c|c|c|c|c|}
\hline Parameters $\mathbf{N}_{\mathbf{A}}\left(\mathbf{c m}^{-\mathbf{3}}\right)$ & $\boldsymbol{J}_{\mathbf{s c}}\left(\mathbf{m A c m}^{-\mathbf{2}}\right)$ & $\boldsymbol{V}_{\boldsymbol{o c}}(\mathbf{V})$ & $\boldsymbol{F F}$ & PCE $(\mathbf{\%})$ \\
\hline $1 \mathrm{E}+13$ & 27.44 & 0.54 & 60.21 & 8.94 \\
$1 \mathrm{E}+14$ & 27.49 & 0.54 & 60.37 & 9.01 \\
$1 \mathrm{E}+15$ & 27.92 & 0.57 & 61.53 & 9.74 \\
$1 \mathrm{E}+16$ & 27.85 & 0.72 & 65.31 & 13.09 \\
$1 \mathrm{E}+17$ & 25.32 & 0.75 & 71.98 & 13.60 \\
\hline
\end{tabular}

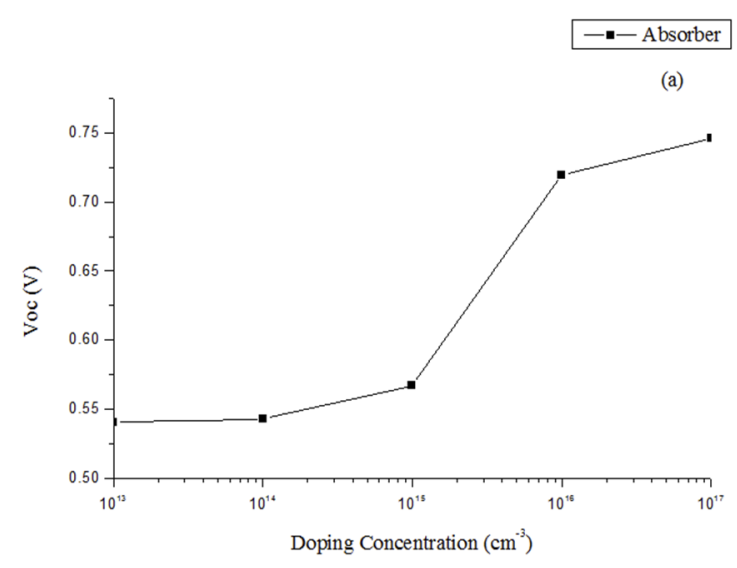

- - Absorber

(d)

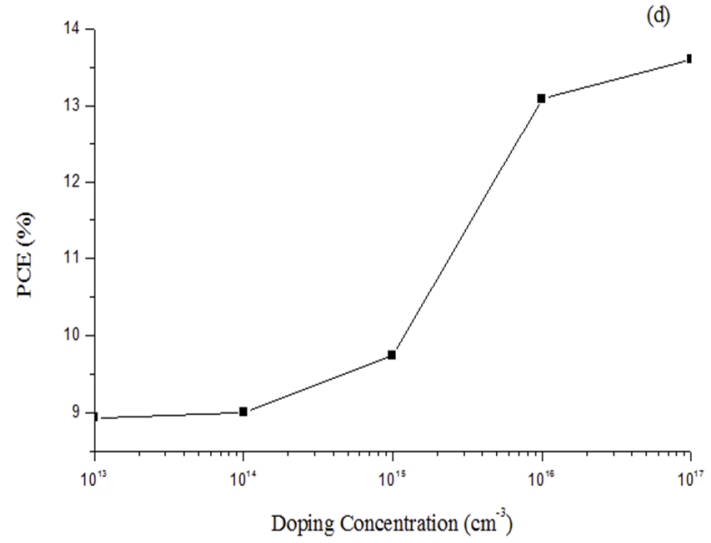

(b)

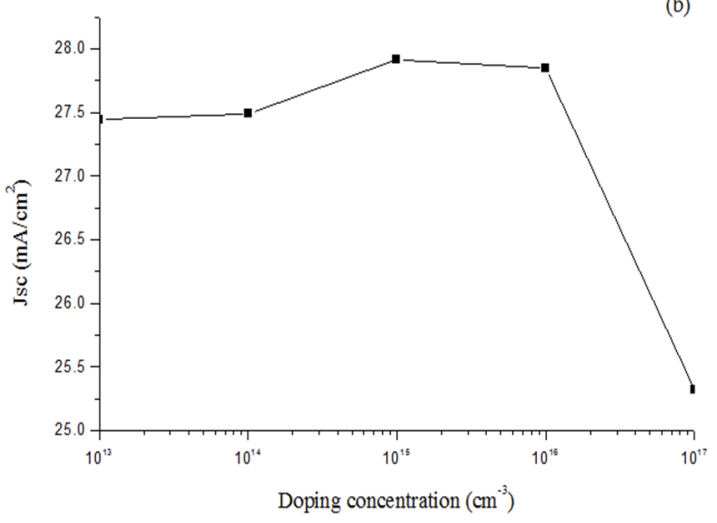

(c)

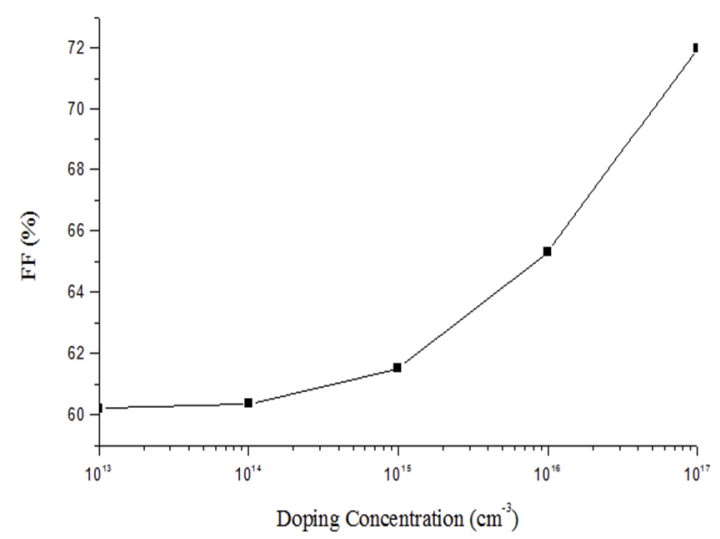

Figure 3. Variation in solar cell parameters with doping concentration of absorber.

The best performing device was obtained when $\mathrm{N}_{\mathrm{A}}$ was set as $1.0 \times 10^{17} \mathrm{~cm}^{-3}$ for the perovskite absorption layer, it gives photovoltaic parameters of $25.32 \mathrm{~mA} / \mathrm{cm}^{2}$ for Jsc, $0.74 \mathrm{~V}$ for $\mathrm{Voc}, 71.98 \%$ for FF and $13.59 \%$ for PCE as depicted in Figure 3. The result of the champion device shows charge carriers are efficiently transported and collected at the $\mathrm{N}_{\mathrm{A}}$ value and that suggests that, for improvement of performance of PSCs, the $\mathrm{N}_{\mathrm{A}}$ should be $1.0 \times 10^{17} \mathrm{~cm}^{-3}$.

Our result further shows that decreasing $\mathrm{N}_{\mathrm{A}}$ beyond $1.0 \times 10^{17}$ a decrease in PCE was observed. The observed decrease in PCE with increasing $\mathrm{N}_{\mathrm{A}}$ is due to increase in Auger recombination rate [5]. When the optimized result is compared with the reference device, we observed an enhancement that is $\sim 17.20 \%$ in Voc, $17.81 \%$ in FF, and $20.35 \%$ in PCE.

\section{Influence of Electron Affinity of HTH and ETM}

The critical factor between $\mathrm{TiO}_{2} /$ perovskite/CuI is band offset which can predict the possibility of carrier recombination at the interface and is the function of $V_{o c}$. By changing the values of electron affinities of $C u I$ ( $2.0 \mathrm{eV}$ $2.8 \mathrm{eV})$ and $\mathrm{TiO}_{2}(3.7 \mathrm{eV}-4.4 \mathrm{eV})$, the band offset can be adjusted. Figure 4 shows the combined variations of $V_{o c}, J_{s c}, \mathrm{FF}$ and PCE with electron affinity of HTM and ETM respectively. Figure 4 explain the variation of PCE, Voc, Jsc and FF with electron affinity of ETM and HTM respectively.

The values of $2.3 \mathrm{eV}$ and $3.7 \mathrm{eV}$ gave the best PCEs for $\mathrm{CuI}$ and $\mathrm{TiO}_{2}$ respectively. Their corresponding photovoltaic parameters are Voc of $0.63 \mathrm{~V}$, Jsc of $30.79 \mathrm{mAcm}^{-2}$, FF of $68.50 \%$ and PCE of $13.32 \%$ for the CuI and Voc of $0.82 \mathrm{~V}$, Jsc of $29.06 \mathrm{mAcm}^{-2}$, FF of $64.87 \%$ and PCE of $15.51 \%$ for the $\mathrm{TiO}_{2}$. Increasing the EA of the ETL above $3.7 \mathrm{eV}$ leads to decrease in PV performances as shown in Table 4.

When the electron affinity of ETM is higher than $3.7 \mathrm{eV}$, the Jsc and PCE decreases. When the electron affinity of HTM is lower than $2.3 \mathrm{eV}$, and above $2.3 \mathrm{eV}$, the PV parameters both decreases as shown in Table 5. 
Table 4. Dependence of solar cell performance on the EA of the ETL

\begin{tabular}{|c|c|c|c|c|}
\hline Parameters EA (eV) & $\boldsymbol{J}_{\boldsymbol{s c}}\left(\mathbf{m A c m}^{-2}\right)$ & $\boldsymbol{V}_{\boldsymbol{o c}} \mathbf{( V )}$ & $\boldsymbol{F F}$ & PCE (\%) \\
\hline 3.7 & 30.79 & 0.63 & 68.50 & 13.33 \\
3.8 & 30.76 & 0.63 & 68.51 & 13.31 \\
3.9 & 30.68 & 0.63 & 68.47 & 13.27 \\
4.0 & 30.44 & 0.63 & 68.31 & 13.13 \\
4.1 & 29.70 & 0.63 & 67.45 & 12.66 \\
4.2 & 28.78 & 0.64 & 64.16 & 11.80 \\
4.3 & 28.33 & 0.65 & 59.17 & 10.81 \\
4.4 & 27.79 & 0.57 & 55.20 & 8.81 \\
\hline
\end{tabular}

Table 5. Dependence of solar cell performance on the EA of HTL

\begin{tabular}{|c|c|c|c|c|}
\hline Parameters EA(eV) & $\boldsymbol{J}_{\boldsymbol{s c}}\left(\mathbf{m A c m}^{-\mathbf{2}}\right)$ & $\boldsymbol{V}_{\boldsymbol{o c}} \mathbf{( V )}$ & $\boldsymbol{F F}$ & PCE (\%) \\
\hline 2.0 & 28.05 & 0.55 & 59.05 & 9.10 \\
2.1 & 28.49 & 0.65 & 61.09 & 11.30 \\
2.2 & 28.82 & 0.75 & 62.79 & 13.54 \\
2.3 & 29.06 & 0.82 & 64.87 & 15.51 \\
2.4 & 29.12 & 0.84 & 62.94 & 15.44 \\
2.5 & 29.13 & 0.85 & 56.06 & 13.83 \\
2.6 & 29.07 & 0.83 & 47.90 & 11.62 \\
2.7 & 29.86 & 0.76 & 41.28 & 9.08 \\
2.8 & 25.24 & 0.69 & 18.40 & 3.18 \\
\hline
\end{tabular}
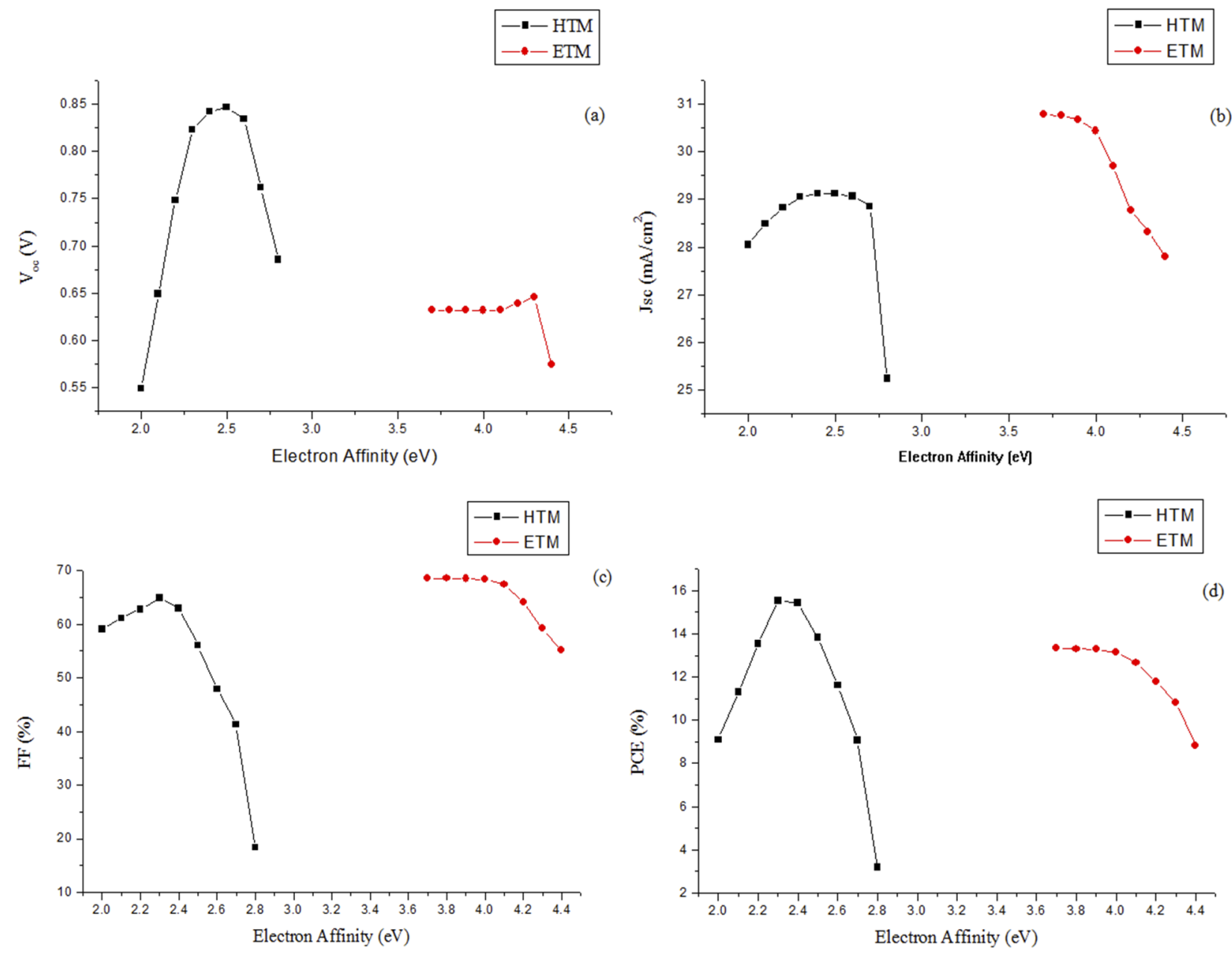

Figure 4. Variation in solar cell parameters with Electron Affinity of HTM and ETM.

It is evident that proper HTM and ETM selection with suitable electron affinity can prevent quenching of carriers and enhanced the performance of PSCs [12].

Effect of the Absorber Thickness on the Device Parameters

Thickness of absorber layer (L), affects the performance of solar cell. The influence of thickness of absorber with variation of performance parameters $V_{o c}, J_{s c}, \mathrm{FF}$ and PCE is shown in the Figure 5. The graphs in Figure 5 show the 
variation in thickness from (0.4-1.3) $\mu \mathrm{m}$ of the absorber against the PV parameters of the PSCs. Figure 5 shows a steady increase in $V_{o c}, J_{s c}$ and PCE from a thickness of $0.5 \mu \mathrm{m}$, while there is a rapid decline in values below $0.5 \mu \mathrm{m}$. There a steady increase in PCE with thickness also conforming with the work of Hafeez et al. [9]. From Figure 5, it could be deduced that the optimum thickness of the absorber is $0.7 \mu \mathrm{m}$, for after this thickness, a steady increment of the PCE value.

Table 6. Dependence of solar cell performance on the thickness of the Absorber layer

\begin{tabular}{|l|c|c|c|c|}
\hline Parameters $\mathbf{N}_{\mathbf{A}}\left(\mathbf{c m}^{-\mathbf{3}}\right)$ & $\boldsymbol{J}_{\mathbf{s c}}\left(\mathbf{m} \mathbf{A c m} \mathbf{c m}^{-\mathbf{2}}\right)$ & $\boldsymbol{V}_{\boldsymbol{o c}} \mathbf{( \mathbf { V } )}$ & $\boldsymbol{F F}$ & PCE $\mathbf{( \% )}$ \\
\hline 0.2 & 23.40 & 0.53 & 65.24 & 8.14 \\
0.3 & 26.78 & 0.58 & 62.79 & 9.83 \\
0.4 & 28.49 & 0.65 & 61.09 & 11.30 \\
0.5 & 29.41 & 0.69 & 62.59 & 12.69 \\
0.6 & 29.91 & 0.71 & 63.61 & 13.46 \\
0.7 & 30.28 & 0.72 & 63.93 & 13.90 \\
0.8 & 30.59 & 0.73 & 63.73 & 14.16 \\
0.9 & 30.82 & 0.73 & 63.33 & 14.33 \\
1.0 & 30.98 & 0.74 & 62.84 & 14.43 \\
\hline
\end{tabular}
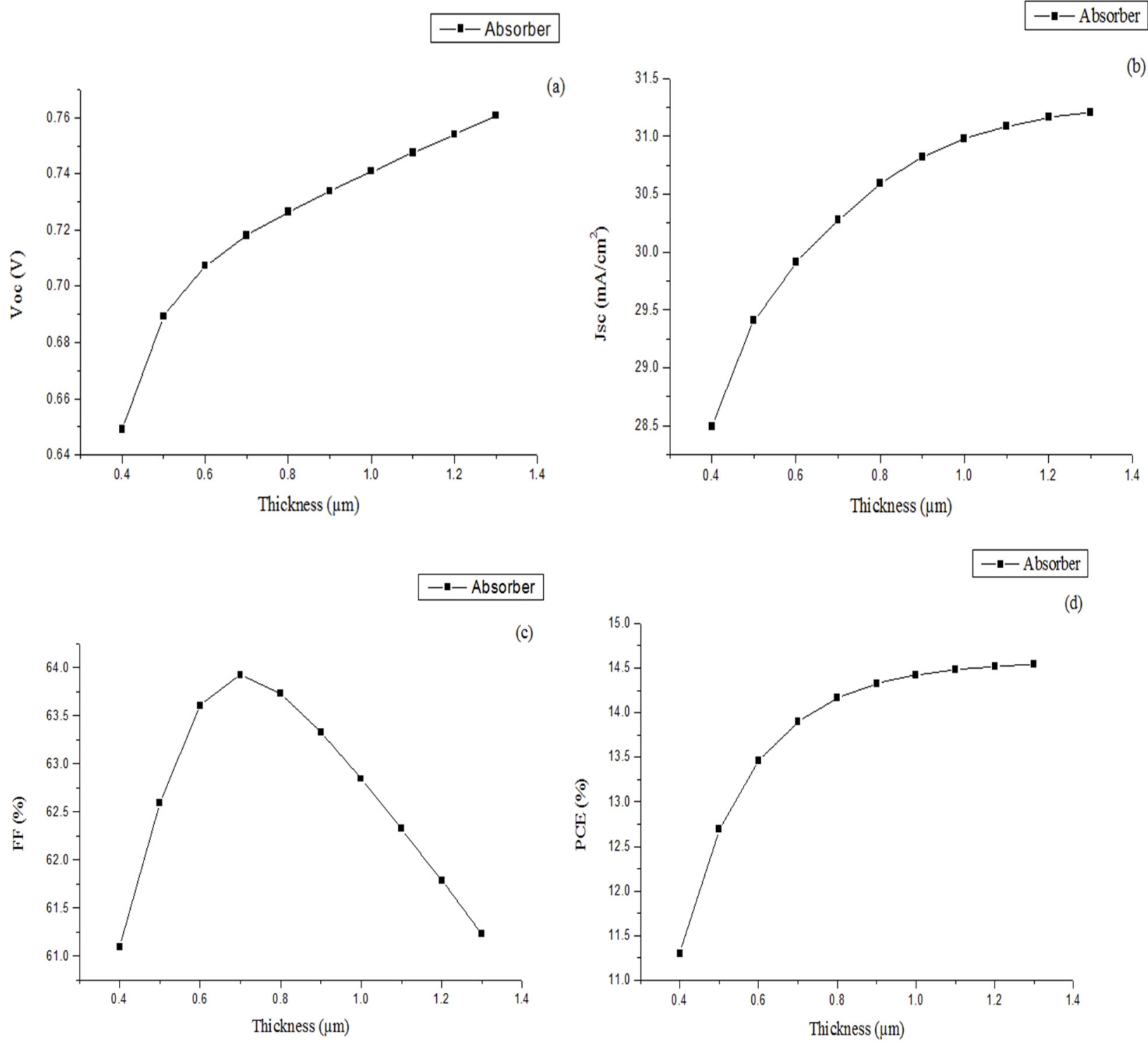

Figure 5. Variation in solar cell parameters with thickness of the absorber.

Influence of Defect Density $\left(N_{t}\right)$ of Absorber Layer

For further improvement in performance of PSC, defect density is one of the crucial parameter worth investigating. The behaviour of PSC is greatly affected by the morphology and quality of absorber layer [13]. When light is irradiated upon 
PSC, photoelectrons are generated in the absorber layer. If the film quality is not good enough, then defect density increases and quenching losses will become unavoidable in absorber layer which determine the Voc of the solar cell.

Table 7. Dependence of solar cell performance on the defect density of the Absorber layer

\begin{tabular}{|l|c|c|c|c|}
\hline Parameters $\mathbf{N}_{\mathbf{A}}\left(\mathbf{c m}^{-\mathbf{3}}\right)$ & $\boldsymbol{J}_{\mathbf{s c}}\left(\mathbf{m A c m}^{-\mathbf{2}}\right)$ & $\boldsymbol{V}_{\boldsymbol{o c}} \mathbf{( V )}$ & $\boldsymbol{F F}$ & PCE (\%) \\
\hline $1 \mathrm{E}+14$ & 28.75 & 0.65 & 62.73 & 11.78 \\
$1 \mathrm{E}+15$ & 28.75 & 0.65 & 62.69 & 11.77 \\
$1 \mathrm{E}+16$ & 28.69 & 0.65 & 62.31 & 11.66 \\
$1 \mathrm{E}+17$ & 28.18 & 0.64 & 59.47 & 10.80 \\
$1 \mathrm{E}+18$ & 24.02 & 0.60 & 47.70 & 6.90 \\
$1 \mathrm{E}+19$ & 9.65 & 0.50 & 29.12 & 1.42 \\
\hline
\end{tabular}

The initial value of $N_{t}$ in the absorber is set to be $4.5 \times 10^{16} \mathrm{~cm}^{-3}$ [8]. Based on previous simulated studies the range of defect density was considered to be $10^{14} \mathrm{~cm}^{-3}$ to $10^{19} \mathrm{~cm}^{-3}$ [7].

Figure 6 depicts the variation of PV parameters with defect density $\left(N_{t}\right)$ of absorber layer. The PV parameters of the PSC is enhanced greatly with decrease in the $\mathrm{Nt}$ in perovskite, which shows agreement with similar studies on the lead perovskite [14]. When defect density is $1.0 \times 10^{16} \mathrm{~cm}^{-3}$ the cell PV property is greatly enhanced reaching a Jsc of 28.75 $\mathrm{mA} / \mathrm{cm}^{2}$, Voc of $0.65 \mathrm{~V}, \mathrm{FF}$ of $62.73 \%$ and PCE of $11.78 \%$. The result conforms with those of Hui-Jing et al., in 2016 [7]. However, realizing such a low defect density experimentally is very difficult, so an optimized value of $1.0 \times 10^{14} \mathrm{~cm}^{-3}$ was set as the defect density making all the values of the PV parameters (Jsc, Voc, FF and PCE) approximately reaching their maximum with the chosen defect density. Experimental studies, however shows that the tin-based perovskite demonstrates good charge-transport characteristics $[15,16]$.
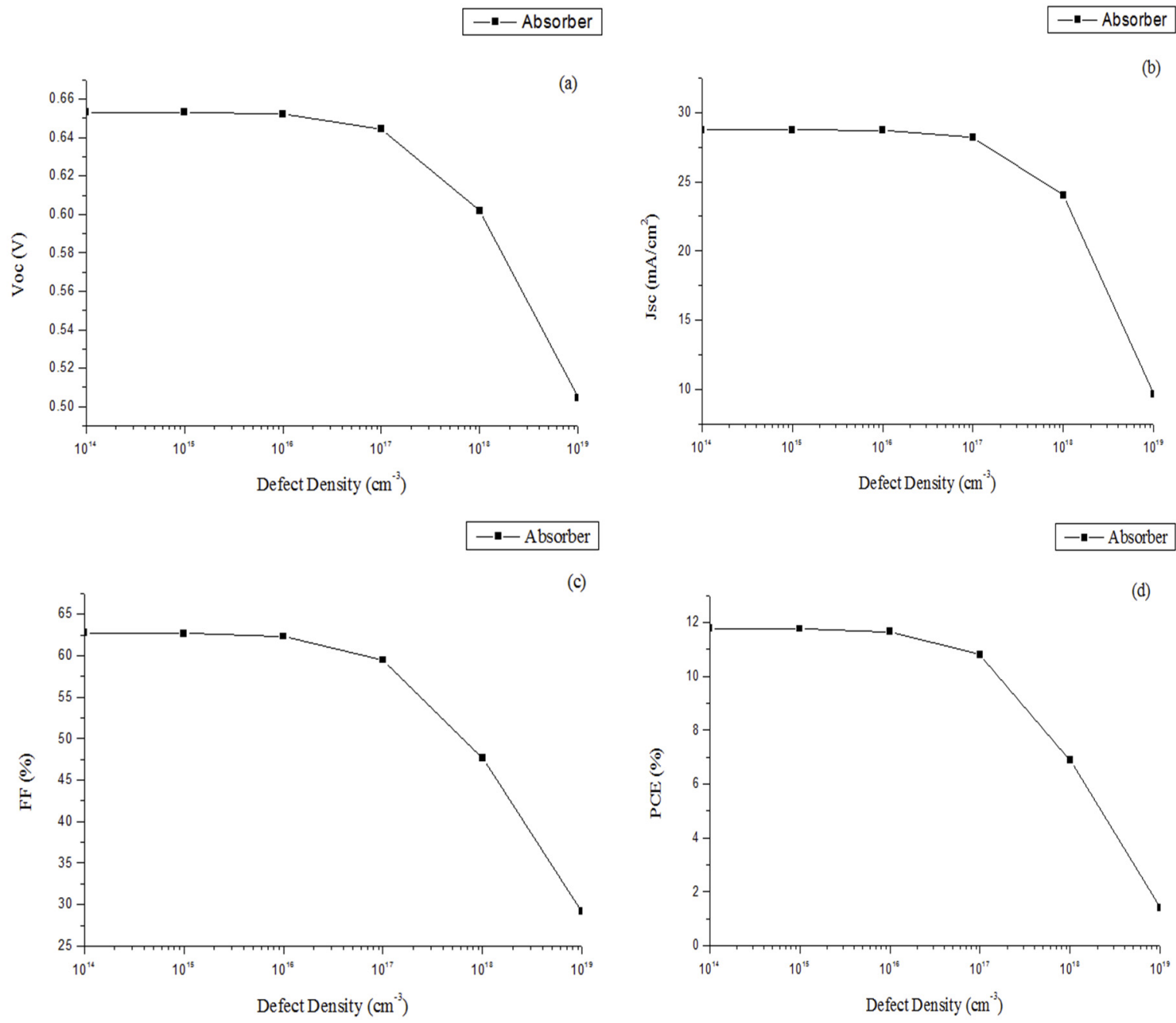

Figure 6. Variation in solar cell parameters with different values of defect density $N_{t}$

Influence of Hole Mobility of HTM

Mobility of charge Carrier in a semiconductor is among the crucial parameters in electronic devices. Actually, it measures the capacity of charge carriers to shuttle in the material as it is exposed to an external electric field. The 
magnitude of the mobility directly impacts on the device performance since it determines the operation speed through the transit time across the device, the circuit operating frequency. Hole mobility is affected by doping level and doping concentration of acceptor. Lattice scattering and ionized impurity scattering limit the hole mobility in the material at low acceptor doping and high acceptor doping respectively.
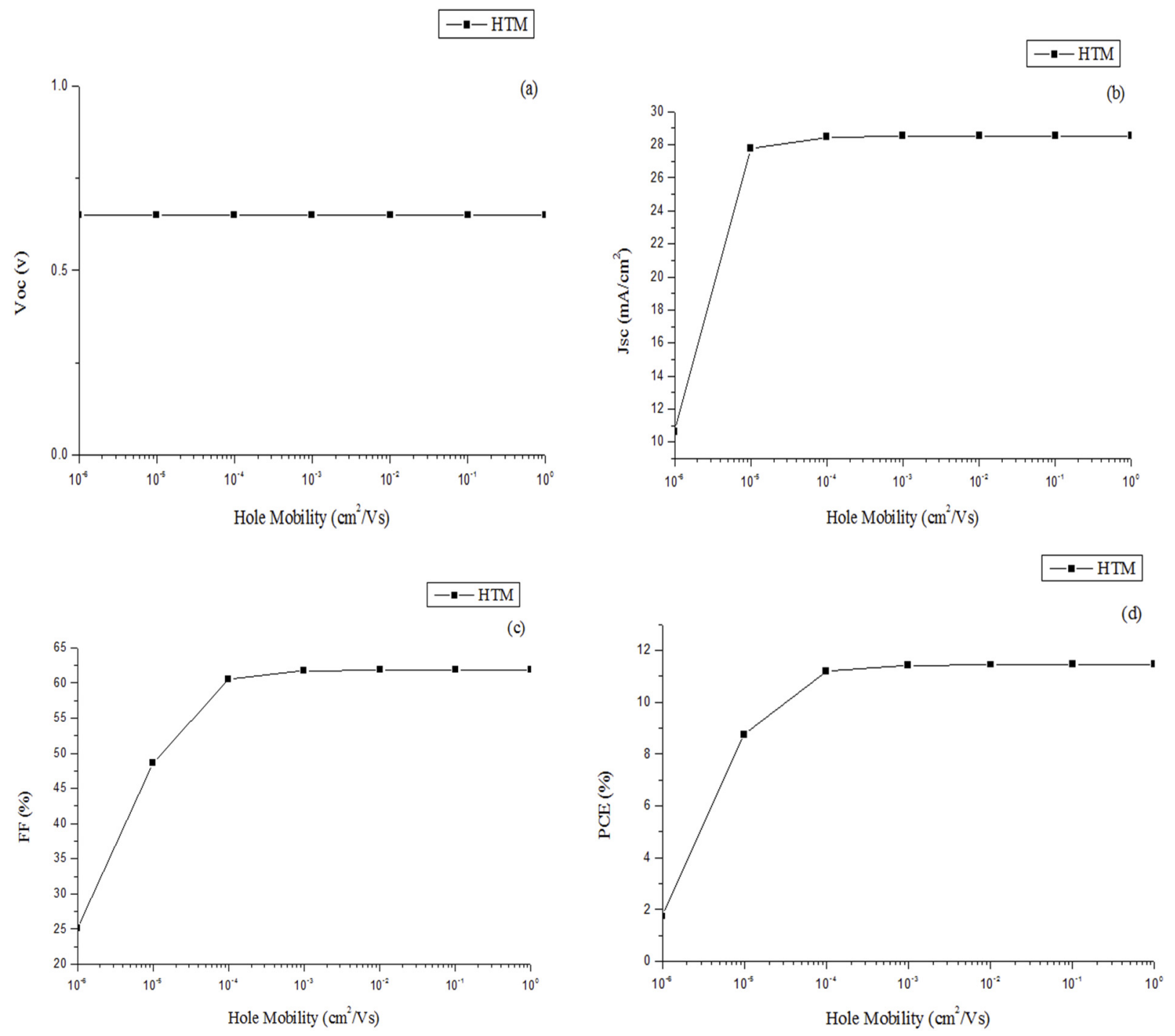

Figure 7. Variation in solar cell parameters with increasing hole mobility of HTM.

The effect of hole mobility in the hole transport material $(C u I)$ has been computed on performance parameters. From Figure 7, (b) and (d) it shows the increase in $J_{s c}$ and PCE with the increase in hole mobility which signifies the better charge transport and charge extraction at the HTM/absorber interface.

Table 8. Dependence of solar cell performance on the hole mobility of HTM

\begin{tabular}{|l|c|c|c|c|}
\hline Parameters $\mathbf{N}_{\mathbf{A}}\left(\mathbf{c m}^{-\mathbf{3}}\right)$ & $\boldsymbol{J}_{\mathbf{s c}}\left(\mathbf{m A c m} \mathbf{A c m}^{-\mathbf{2}}\right)$ & $\boldsymbol{V}_{\boldsymbol{o c}}(\mathbf{V})$ & $\boldsymbol{F F}$ & PCE (\%) \\
\hline 1E-06 & 10.65 & 0.65 & 25.11 & 1.74 \\
1E-05 & 27.76 & 0.65 & 48.57 & 8.75 \\
1E-04 & 28.47 & 0.65 & 60.54 & 11.18 \\
1E-03 & 28.52 & 0.65 & 61.73 & 11.43 \\
1E-02 & 28.53 & 0.65 & 61.87 & 11.46 \\
1E-01 & 25.53 & 0.65 & 61.88 & 11.46 \\
1E+00 & 28.53 & 0.65 & 61.88 & 11.46 \\
\hline
\end{tabular}

\section{Performance of Optimized parameters}

Considering all the varied parameters after simulation, such as $\mathrm{N}_{\mathrm{A}}$, electron affinity, $\mathrm{Nt}$ thickness and Hole mobility, a PCE of $20.35 \%$ with Jsc of $31.38 \mathrm{mAcm}^{-2}$, voltage of $0.84 \mathrm{~V}$, and FF of $76.94 \%$, which shows an improvement 
of $\sim 1.80$ times in PCE, $\sim 1.10$ times in Jsc, 1.26 times in FF and 1.31 times in Voc over the initial cell. The final optimized parameters and optimised J-V curve are shown in Table 9(a) and Figure 8 respectively. The result was compared to other simulated and experimental work published by other researchers and the related data is summarized in Table 9(b). In Table 9(b), the best experimental PCE is $17.60 \%$ with CuI as HTM. The Voc, FF and Jsc still need to be enhanced to achieve $20.35 \%$ PCE.

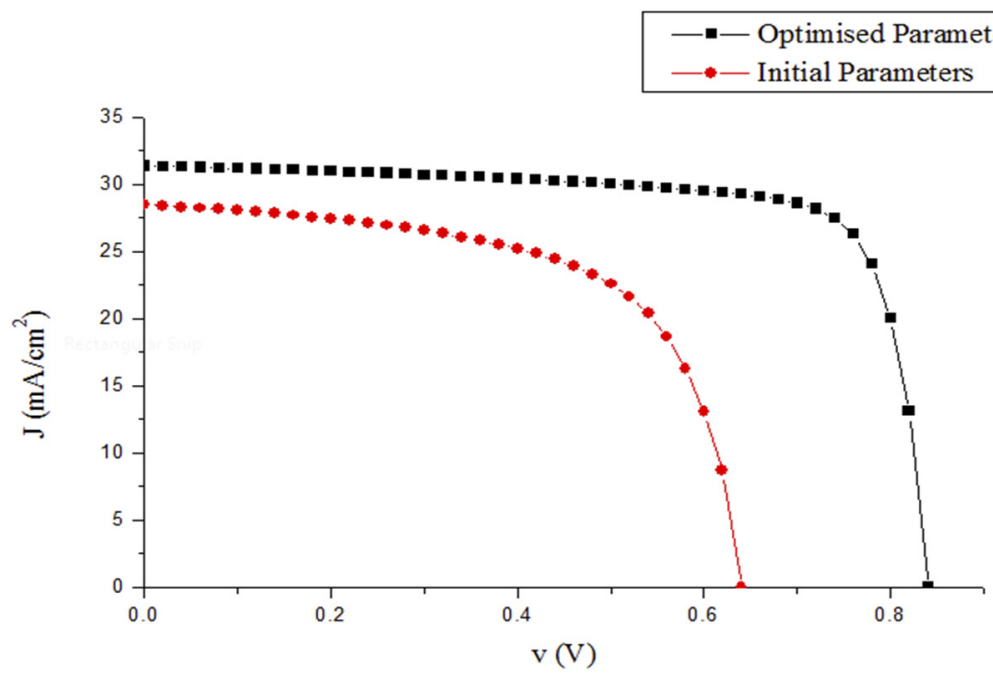

Table 9(a). Optimized parameters of the simulated device

\begin{tabular}{|l|c|c|c|}
\hline Optimized parameters & $\mathrm{TiO}_{2}(\mathrm{ETL})$ & $\mathrm{CH}_{3} \mathrm{NH}_{3} \mathrm{SnI}_{3}$ (absorber) & $\mathrm{CuI}(\mathrm{HTL})$ \\
\hline Doping density $\left(\mathrm{cm}^{-3}\right)$ & --- & $1.0 \times 10^{16}$ & -- \\
\hline Electron affinity $(\mathrm{eV})$ & 3.7 & --- & --- \\
\hline Defect density $\left(\mathrm{cm}^{-3}\right)$ & --- & $1.0 \times 10^{16}$ & --- \\
\hline Thickness $(\mu \mathrm{m})$ & --- & 0.7 & $1.0 \times 10^{-2}$ \\
\hline Hole mobility $\left(\mathrm{cm}^{2} / \mathrm{Vs}\right)$ & --- & --- & \\
\hline
\end{tabular}

Table 9(b). Photovoltaic parameters of CuI and Tin (Sn) based perovskite solar cells of some reported experimental and simulated works from literature using SCAPS-1D

\begin{tabular}{|c|c|c|c|c|c|c|}
\hline \multirow{2}{*}{ Device } & \multicolumn{4}{|c|}{ Parameters } & \multirow{2}{*}{ Reference } & \multirow{2}{*}{ Experiment/Simulation } \\
\hline & PCE (\%) & FF (\%) & $\mathrm{Jsc}\left(\mathrm{mA} / \mathrm{cm}^{2}\right)$ & $\operatorname{Voc}(\mathrm{V})$ & & \\
\hline $\mathrm{CH}_{3} \mathrm{NH}_{3} \mathrm{SnI}_{3} / \mathrm{CuI}$ & 20.35 & 76.94 & 31.38 & 0.84 & Current & Simulation \\
\hline $\mathrm{CH}_{3} \mathrm{NH}_{3} \mathrm{PbI}_{3} / \mathrm{CuI}$ & 21.32 & 84.53 & 25.47 & 0.99 & [9] & Simulation \\
\hline $\mathrm{CH}_{3} \mathrm{NH}_{3} \mathrm{SnI}_{3} / \mathrm{Cu}_{2} \mathrm{O}$ & 20.23 & 74.02 & 32.26 & 0.85 & {$[8]$} & Simulation \\
\hline $\begin{array}{l}\mathrm{CH}_{3} \mathrm{NH}_{3} \mathrm{SnI}_{3} / \mathrm{S}- \\
\mathrm{OMETaD}\end{array}$ & 6.40 & 42 & 16.80 & 0.88 & {$[17]$} & Experiment \\
\hline $\mathrm{CH}_{3} \mathrm{NH}_{3} \mathrm{PbI}_{3} / \mathrm{CuI}$ & 17.60 & 75 & 22.78 & 1.03 & {$[18]$} & Experiment \\
\hline $\mathrm{CH}_{3} \mathrm{NH}_{3} \mathrm{PbI}_{3} / \mathrm{Cu}_{2} \mathrm{I}$ & 7.5 & 57 & 16.7 & 0.78 & [19] & Experiment \\
\hline
\end{tabular}

\section{CONCLUSION}

Lead-free perovskite solar cells were simulated using SCAPS-1D software. An optimal thickness $(0.7 \mu \mathrm{m})$ and optimal doping concentration $\left(1.0 \times 10^{16} \mathrm{~cm}^{-3}\right)$ of the absorber layer were identified, exceeding which will lead to degradation of solar cell performance. The simulation shows that $N_{t}$ is an crucial factor to measure the PV parameters of PSCs, and the result is consistent with the researches on $\mathrm{CH}_{3} \mathrm{NH}_{3} \mathrm{PbI}_{3}$ perovskite cell. Considering all the factors such as doping density, electron affinity, defect density and thickness, an encouraging result was obtained, Jsc of $31.38 \mathrm{~mA} / \mathrm{cm}^{2}$, Voc of $0.84 \mathrm{~V}, \mathrm{FF}$ of $76.94 \%$ and PCE of $20.35 \%$.

The final optimized parameters and optimised J-V curve were obtained. Comparison was done with other simulated results and experimental works published by the other researchers. In the literature, the best efficiency of $17.60 \%$ has been achieved for PSCs with $\mathrm{CuI}$ as HTM. Voc of $1.03 \mathrm{~V}$ reported in the literature is already higher than the value through this work, while the FF and Jsc still need be increased to achieve $21.32 \%$ efficiency.

\section{ACKNOWLEDGMENTS}

The authors would like to thank Professor Marc Burgelman, Department of Electronics and Information Systems, University of Ghent for the development of the SCAPS software package and allowing its use. 


\section{REFERENCES}

[1] Z. Wang, Q. Lin, F.P. Chmiel, N. Sakai, L.M. Herz, and H.J. Snaith, Nature Energy, 2, 17135 (2017), https://doi.org/10.1038/nenergy.2017.135.

[2] Y. Liu, Z. Yang, D. Cui, X. Ren, J. Sun, X. Liu, J. Zhang, Q. Wei, H. Fan, F. Yu, X. Zhang, C. Zhao, and S. Liu, Advanced Materials, 27, 5176-5183 (2015), https://doi.org/10.1002/adma.201502597.

[3] D. Yang, Z. Yang, W. Qin, Y. Zhang, S. Liu, and C. Li, Journal of Materials Chemistry A, 3, $9401-9405$ (2015), https://doi.org/10.1039/C5TA01824B.

[4] A. Kojima, K. Teshima, Y. Shirai, and T. Miyasaka, Journal of the American Chemical society, 131(17), 6050-6051 (2009), https://doi.org/10.1021/ja809598r.

[5] D. Eli, M.Y. Onimisi, S. Garba, R.U. Ugbe, J.A. Owolabi, O.O. Ige, G.J. Ibeh, and A.O. Muhammed, J. Nig. Soc. Phys. Sci. 1, 72-81 (2019), https://doi.org/10.46481/jnsps.2019.13.

[6] NREL Efficiency chart, (2019), https://www.nrel.gov/pv/assets/images/efficiencychart- 20180716.jpg.

[7] D. Hui-Jing, W. Wei-Chao, and Z. Jian-Zhuo, Chinese Phys. B, 25, 108802 (2016), https://doi.org/10.1088/16741056/25/10/108802.

[8] A. Farhana, M. Rafee, S.S. Sakin, and M.U. Saeed, International Journal of Photoenergy, 9846310 (2017), https://doi.org/10.1155/2017/9846310.

[9] Syed Zulqarnain Haider, Hafeez Anwar, and Mingqing Wang, Semicond. Sci. Technol. 33(3), 035001 (2018), https://orcid.org/0000-0002-0473-850X.

[10] F. Hao, C.C. Stoumpos, R.P.H. Chang, and M.G. Kanatzidis, J. Am. Chem. Soc. 136(22), 8094-8099 (2014), https://doi.org/10.1021/ja5033259.

[11] F. Hao, C.C. Stoumpos, P. Guo, N. Zhou, T.J. Marks, R.P.H. Chang, and M.G. Kanatzidis, J. Am. Chem. Soc. 137, 11445 (2015), https://doi.org/10.1021/jacs.5b06658.

[12] K.G. Lim, S. Ahn, Y.H. Kim, Y. Qi, and T.W. Lee, Energy Environ. Sci. 9, 932-939 (2016), https://doi.org/10.1039/C5EE03560K.

[13] H. Kim, K.G. Lim, and T.W. Lee, Energy Environ. Sci. 9, 12-30 (2016), https://doi.org/10.1039/C5EE02194D.

[14] F. Hao, K. Stoumpos, D. H. Cao, R. P. H. Chang, and M. Kanatzidis, Nature Photonics, 8(6), 489-494 (2014) https://doi.org/10.1038/nphoton.2014.82.

[15] D.B. Mitzi, C.A. Field, Z. Schlesinger, and R.B. Laibowitz, J. Solid State Chem. 114, 159-163 (1995), https://doi.org/10.1006/jssc.1995.1023.

[16] D.Y. Liu, M.K. Gangishetty, and T.L. Kelly, J. Mater. Chem. A, 2, 19873-19881 (2014), https://doi.org/10.1039/C4TA02637C.

[17] N.K. Noel, D.S. Samuel, A. Antonio, W. Christian, G. Simone, H. Amir-Abbas, S. Aditya, E.E. Giles, K.P. Sandeep, B.J. Michael, P. Annamaria, M.H. Laura, and J.S. Henry, Energy Environ. Sci. 7, 3061-3068 (2014), https://doi.org/10.1039/c4ee01076k.

[18] X. Li, J. Yang, Q. Jiang, W. Chu, D. Zhang, Z Zhou, and J. Xin, ACS Appl. Mater. Interfaces, 7b, 14926 (2017), https://doi.org/10.1021/acsami.7b14926.

[19] G.A. Sepalage, S. Meyer, A. Pascoe, A.D. Scully, F. Huang, U. Bach, Y.B Cheng, and L. Spiccia, Adv. Funct. Mater. 25, 5650-5661 (2015), https://doi.org/10.1002/adfm.201502541.

\section{МОДЕЛЮВАННЯ ТА ІМІТАЦІЯ БЕЗСВИНЦЕВОГО ПЕРОВСКІТНОГО СОНЯЧНОГО ЕЛЕМЕНТА 3 ВИКОРИСТАННЯМ ПРОГРАМИ SCAРS-1D}

Омейза Абдулмалік Мухаммед ${ }^{\mathrm{a}}$, Елі Данладі ${ }^{\mathrm{b}, \mathrm{e}}$, Пітер Генрі Бодуку ${ }^{\mathrm{c}}$, Джаміля Тасюс, Мухаммад Сани Ахмад

${ }^{a}$ Фізичний факультет, Університет Байєр, Кано, Нігерія

${ }^{b}$ Фізичний факультет, Нігерійська академія оборони, Кадуна, Нігерія

'Фізичний факультет, Університет штату Кадуни, Кадуна, Нігерія

${ }^{d}$ Факультет математичних наук, Університет штату Кадуна, Кадуна, Нігерія

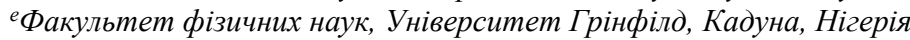

У цій роботі було вивчено вплив деяких параметрів на перовскітний сонячний елемент (PSC) на основі олова $\left(\mathrm{CH}_{3} \mathrm{NH}_{3} \mathrm{SnI}_{3}\right)$ шляхом моделювання пристрою щодо регулювання концентрації легування перовскітного поглинаючого шару, його товщини та спорідненості транспортного середовища електронів та дірково-транспортувального середовища до електрону, а також щільності дефектів перовскітного поглинаючого шару та рухливості дірок в дірково-транспортувальному матеріалі (HTM). Моделюючий пристрій: програма одномірного імітатора ємності сонячних елементів (SCAPS-1D) була використана для моделювання перовскітних сонячних елементів на основі олова. Крива вольтамперноі характеристики (J-V), отримана шляхом моделювання пристрою без оптимізації, показує вихідні параметри елемента, які включають: напругу розімкнутого контуру $\left(V_{o c}\right)=0,64 \mathrm{~B}$, щільність струму короткого замикання $\left.U_{s c}\right)=28,50 \mathrm{~mA} / \mathrm{cm}^{2}$, коефіцієнт заповнення $(\mathrm{FF})=61,10 \%$ та ефективність перетворення потужності $(\mathrm{PCE})=11,30 \%$ при імітованому АМ1,5, сонячному світлі, $=100 \mathrm{MBT} / \mathrm{cm}^{2}$ при $300 \mathrm{~K}$. Після оптимізації було визначено, що значення концентрації легування, щільності дефектів, спорідненості до електронів матеріалу для транспортування електронів та дірково-транспортувального матеріалу становлять: $1.0 \times 10^{16} \mathrm{~cm}-3$, $1.0 \times 10^{15} \mathrm{~cm}^{-3}, 3.7 \mathrm{eB}$ та 2,3 еВ відповідно. Порівняно 3 початковим пристроєм без оптимізації, були отримані помітні значення параметрів сонячних елементів при $J_{s c}=31,38 \mathrm{~mA} / \mathrm{cm}^{2}, V_{o c}=0,84 \mathrm{~B}, \mathrm{FF}=76,94 \%$ та PCE $=20,35 \%$, що демонструє поліпшення в $\sim 1,10$ рази для Јsc, $\sim 1,80$ рази для $\mathrm{PCE}, \sim 1,31$ рази для $\mathrm{V}_{\text {oc, }}$ та $\sim 1,26$ рази для FF. Результати показують, що безсвинцевий $\mathrm{CH}_{3} \mathrm{NH}_{3} \mathrm{SnI}_{3}$ перовскітний сонячний елемент, який $є$ екологічно чистим, $є$ потенційним сонячним елементом 3 високою теоретичною ефективністю $20,35 \%$.

КЛЮЧОВІ СЛОВА: шар транспортування електронів, дірково-транспортувальний шар, перовскітний сонячний елемент, фотоелектричний, SCAPS-1D, йодід міді 